SECTION 21. Pedagogy. Psychology. Innovations in the field of education.

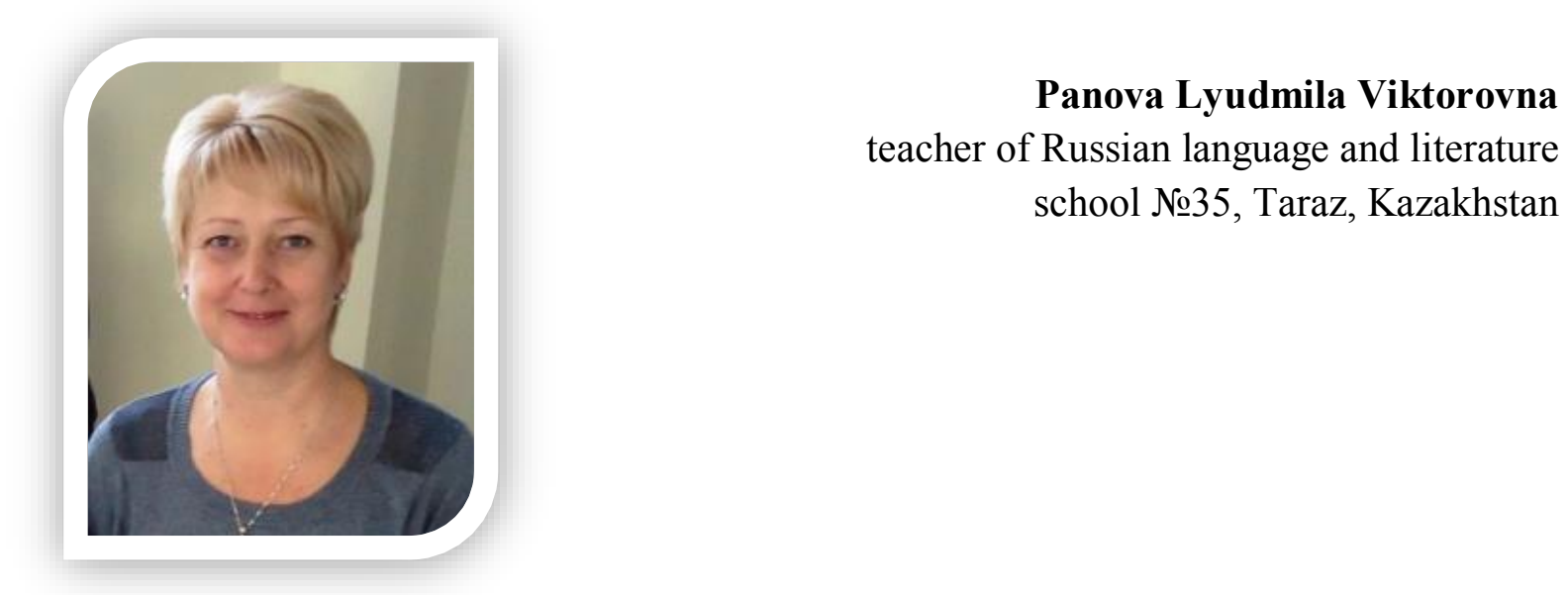

\title{
PRACTICAL COURSE ON THE RUSSIAN LANGUAGE. SPEECH ERRORS STUDENTS.
}

\begin{abstract}
The development of speech of students can be attributed to one of the main tasks of the teacher of the Russian language. The formation of the language skills of the students is carried out continuously during all the years of teaching the Russian language at studying all course units in each class. Published quite a lot of textbooks on stylistics and speech development, but, despite this, the problem of speech errors has been and remains one of the most pressing educational problems.
\end{abstract}

Key words: speech errors, noun, linguistics.

\section{ПРАКТИКУМ ПО РУССКОМУ ЯЗЫКУ. РЕЧЕВЫЕ ОШИБКИ УЧАЩИХСЯ.}

Аннотация: Развитие речи учащихся можно отнести к одной из основных задач, стоящих перед учителем русского языка. Формирование речевых навыков учашихся ведется непрерывно на протяжении всех лет обучения русскому языку, при изучении всех разделов курса, в каждом классе. Издается довольно много пособий по стилистике и развитию речи, но, несмотря на это, проблема речевых ошибок была и остаётся одной из самых острых учебных проблем.

Ключевые слова: речевые ошибки, имя существительное, лингвистика.

Известно, что лишь точная квалификация допущенной учеником ошибки и верное определение еe лингвистического механизма - залог успешной работы по предупреждению подобных ошибок в дальнейшем [1]. Тема занятия — «Имя существительное. Одушевленность - неодушевленность. Категория рода. Категория числа».

\section{Имя существительное}

1. Ошибки, связанные с категорией одушевленности-неодушевленности существительных, встречаются преимущественно в речи младших школьников [2]. Проанализируйте причины приведенных ниже ошибок.

1) Девочка уложила куклы спать и стала ждать маму. 2) Я бы хотел иметь какогонибудь животного, чтобы за ним ухаживать. 3) Этих статуй я сразу же заметил. 4) Я поймал три карася, а Сережа ни одного. 5) Когда он нес важные бумаги, ему в провожатые давали два чекиста. 6) А проворная курица в это время ела Бовины 
червяки. 7) Два медведя запрягали в сани и сажали туда гостей. 8) Все смотрели на него как на призрака.

2. Приводимые ниже речевые факты связаны с категорией рода. Проанализируйте их, разграничивая следующие случаи: а) не соответствующее норме употребление существительных общего рода; б) ненормативное использование существительных мужского рода по отношению к лицам женского пола и связанные с этим речевые явления.

1) Мальчик рос круглой сиротой. 2) Я бы хотела скорее стать пионером. 3) Она всегда хочет быть командирской. 4) Вызывали врача, а пришла врачиха! 5) Фетида был бог? 6) У нас не математик, а математичка. 7) Мужчине стыдно быть такой плаксой. 8) Моя бабушка во время войны была летчиком. 9) Маша Миронова — главный герой повести «Капитанская дочка».

3. Какие из приведенных ниже предложений содержат речевые неправильности?

1) Когда я перелезал через забор, одна валенка свалилась. 2) Куда подевалась моя туфля? 3) Бим умеет, приносит хозяину тапки. Правда, он приносит только один тапок. 4) Какая красивая георгина! 5) Когда у папы оторвалась одна погона, я ее пришила. 6) Один галош он потерял на улице. 7) Он нажал на один клавиш, потом на другой.

4. Есть ли речевые неправильности в приведенных ниже фразах?

1) Большое окно занавешено красивой белой тюлью. 2) В ванной у нас полка с мылом и шампунем. 3) Возьми синюю гуашь и напиши объявление. 4) Гринев, как он сам говорил, жил недорослью. 5) На месте дома теперь один горький полынь. 6) Мы вчера пекли пирог с повидлой. 7) На одном из них красная казакина. 8) Самый большой яблок она дала младшей сестренке.

5. Как определяется отнесенность к тому или другому роду существительных с ласкательно-уменьшительными или увеличительными суффиксами? В чем причина приведенных ниже ошибок? [3-7]

Огромное носище, старинное городишко, ветхое домишко, хитрое умишко.

6. В чем, по вашему мнению, заключается причина следующих речевых ошибок, связанных с определением рода несклоняемых существительных?

1) К дому подкатила новенькая такси. 2) Авторитетная жюри присудила этому фильму первую премию. 3) Меня выучили танцевать старинный танго. 4) На завтрак я иногда пью сладкое кофе с молоком. 5) Огромная шимпанзе металась в клетке.

7. Ниже приведены примеры речевых ошибок, заключающихся в том, что учащиеся образовали форму мн. числа существительных, в нормативном языке этой формы не Определите, что в каждом случае послужило стимулом модификации форм числа. ч

1) Берег реки зарос кустарниками. 2) Мы при-казали сдать все оружия. 3) Пролетариата всех стран должны объединиться. 4) Крышу обычно крою железами. 5) Чтобы обрадовать маму, мы с братом вымыли все посуды. 6) В этой книжке много разных юморов. 7) Я бы хотел придумывать разные волшебства, чтобы всем жилось на свете хорошо. 8) Перед тем как идти в поход, мы запаслись палаткой, чайником, разными продовольствиями. 9) Солдат плыл вперед, раздвигая грудью льды. Он хотел скорей вытащить мальчика. 10) Книги формируют наши мировоззрения. 11) У всех цветов свои запахи.

8. В чем заключаются приведенные ниже речевые ошибки, и чем они вызваны[8$11]$ ?

1) Мы с ребятами решили сделать во дворе качель. 2) Каждому выдали по одной грабле, и мы взялись за работу. 3) Добрыня любит музыку, он даже играет на гусле. 4) Левое перило на террасе сломано. 5) У меня кончилось чернило, я больше не могу писать. 6) Подоконник у нас выкрашен белилом.

Ответы 
1.Случаи 1, 4, 5, 6, 7 - употребление одушевленных существительных в качестве неодушевленных, случаи 2, 3, 8 - употребление неодушевленных существительных в качестве одушевленных. Ошибки, связанные с одушевленностью-неодушевленностью, выявляются только при употреблении существительных в форме винительного падежа.

2. В предложениях 1 и 7 существительные общего рода (сирота, плакса), будучи употребленными по отношению к лицам мужского пола, должны были бы иметь при себе прилагательные или местоимения в форме мужского рода. Между тем в данном случае согласование осуществляется не по семантическому, а по формальному основанию: оказывается более существенным наличие флексий, типичных для существительных женского рода. В случаях 3, 4, 6 школьник протестует против нелогичного, с его точки зрения, использования существительных мужского рода по отношению к лицам женского пола, что является весьма распространенным в современном языке (ср.: Она - прекрасный врач). Для наименования лиц женского пола путем суф-фиксации образованы родовые корреляты (командир - «командирка» - ср. пионер - пионерка) или использованы разговорные лексемы (математичка, врачиха). В примерах $2,5,8,9$, напротив, приняв как данность эту особенность современного словоупотребления, учащиеся распространяют ее на все случаи использования существительных со значением лица, в то время как наличие в нормативном языке корреляций пионер - пионерка, бог - богиня, летчик - летчица, герой - героиня делает излишним употребление существительных мужского рода по отношению к лицам женского пола.

3. Неправильности имеются в предложениях 1, 3, 4, 5, 6, 7. См. словарьсправочник «Трудности словоупотребления и варианты норм русского литературного языка» (под ред. К. С. Горбачевича) или другие справочные издания и словари.

4. Неправильности имеются в предложениях 1, 4, 5, 6, 7, 8. Неверное определение родовой принадлежности слов тюль, шампунь, повидло, яблоко широко распространено в просторечии, так что ошибки в этих случаях могут быть обусловлены воздействием речевой среды.

5. Род подобных существительных, как известно, дублирует род существительных, от которых данные слова образованы. Однако внешние формальные признаки (наличие окончаний -е- и -о-) провоцируют их ошибочное отнесение к среднему роду.

6. В первых трех предложениях наверное определение рода связано, повидимому, с воздействием рода синонимичного слова или слова, являющегося гиперонимом по отношению к данному (ср.: такси - машина, жюри - комиссия, танго - танец). Ошибка в определении рода слова кофе является весьма устойчивой (ряд исследо-вателей считает употребление слова кофе как существительного среднего рода допустимым в разговорной речи). Причина данного явления - уподобление этого слова всем другим несклоняемым неодушевленным существительным, которые относятся к среднему роду (кашне, шоссе, какао, радио и т. п.). В 5-м предложении род существительного определяется, по-видимому, реальным полом животного.

7. В предложениях 1, 2, 3, 5, 8 в форме мн. числа употреблены существительные, относящиеся к разряду собирательных. Такое употребление связано с неосознанным стремлением детей подчеркнуть множественность, расчлененность отображаемых языком объектов. В предложениях 4 и 9 в форме мн. числа употреблены вещественные существительные, в предложениях 6, 7, 10, 11 - отвлеченные. Дети склонны образовывать соотносительные формы мн. числа у существительных всех разрядов, тогда как в нормативном языке противопоставление единичности-множественности, основанное на реальных количественных различиях, характерно только для конкретнопредметных считаемых существительных. 
8. Существительные, употребляемые только в форме мн. числа (так наз. pluralia tantum), составляют известную аномалию в ряду других существительных. Многие дети (особенно часто - дошкольники) осмысливают существительное в форме мн. числа как отражающее реальное множество предметов и поэтому образуют отсутствующую в нормативном языке форму ед. числа.

\section{Выводы:}

Исследование возникновения, и разработка методик исправления речевых ошибок учащихся - важный и ответственный процесс в работе учителя русского языка. От ее качества зачастую зависит формирование умений и навыков связного изложения мыслей в устной и письменной форме, обогащение словарного запаса и грамматического строя речи учащихся, овладение нормами русского литературного языка.

\section{Литература:}

1. Корчигина И.Б. Работа над речевыми ошибками как средство овладения нормами речи. [Электронный ресурс]. URL: http://nsportal.ru/shkola/russkiiyazyk/library/doklad-rabota-nad-rechevymi-oshibkami-kak-sredstvo-ovladeniyanormami-r (дата обращения 15.01.2014 г.).

2. Смирнов Ю. Б. ЗАМЕТКИ О КАТЕГОРИИ ОДУШЕВЛЕННОСТИ / НЕОДУШЕВЛЕННОСТИ. Глагольные и именные категории в системе функциональной грамматики. - СПб., 2013. - С. 291-295

3. Пешковский А.М. Русский синтаксис в научном освещении. М. :Учпедгиз, 1986

4. Хабургаев Г.А. Очерки исторической морфологии русского языка.Имена. М.: Издво МГУ,1990.

5. Алгазина Н. Н. Предупреждение орфографических ошибок учащихся V-VIII классов. - М., "Просвещение", 2001;

6. Львов М. Р. Основы обучения правописанию в начальной школе. - М., 1999

7. Львов М. Р. Правописание в начальных классах. -М., 2000

8. Орфография и русский язык. - М., 2003

9. Текучев А. В. Основы методики орфографии в условиях местного диалекта. - М., 1999.

10. Шмелев Д.Н. Архаические формы в современном русском языке. М.: Просвещение, 1960.

11. Пелих В.М., Абдульманова А.К. Историческая грамматика русского языка. Самара, 1994. 